\title{
The Effect of annealing temperature on the optical properties of $\left(\mathrm{Cu}_{2} \mathrm{~S}\right)_{100-\mathrm{x}}\left(\mathrm{SnS}_{2}\right)_{\mathrm{x}}$ thin films
}

\author{
Nada Khdair Abbas* \\ Nadia Jasim Ghdeeb* \\ Anwar Ali Baker*
}

Received 20, December, 2012

Accepted 11, March, 2014

\begin{abstract}
:
Thin films of $\left(\mathrm{Cu}_{2} \mathrm{~S}\right)_{100-\mathrm{x}}\left(\mathrm{SnS}_{2}\right)_{\mathrm{x}}$ at $\left.\mathrm{X}=[\mathrm{30}, 40, \quad \& 50)\right] \%$ with thickness $(0.9 \pm 0.03) \mu \mathrm{m}$, had been prepared by chemical spray pyrolysis method on glass substrates at $573 \mathrm{~K}$. These films were then annealed under low pressure of $\left(10^{-2}\right) \mathrm{mbar}$ $(3736423 \& 473) \mathrm{K}$ for one hour. This research includes, studying the the optical properties of $\left(\mathrm{Cu}_{2} \mathrm{~S}\right)_{100-\mathrm{x}}-\left(\mathrm{SnS}_{2}\right)_{\mathrm{x}}$ at $\left.\mathrm{X}=[30,40, \& 50)\right] \%$.Moreover studying the effect of annealing on their optical properties , in order to fabricate films with high stability and transmittance that can be used in solar cells. The transmittance and absorbance spectra had been recorded in the wavelength range $(310-1100) \mathrm{nm}$ in order to study the optical properties. It was found that these films had direct optical band gap which decreases with the increasing $\mathrm{SnS}_{2}$ ratio, while it increasing with the increase in the annealing temperature at all ratio
\end{abstract}

Key words: $\mathrm{Cu}_{2} \mathrm{~S}$ films , $\mathrm{SnS}_{2}$ films, structure properties, optical properties

\section{Introduction:}

In the past few years, the synthesis and physical characterization of nanoscale semiconductors have aroused much interest [1]. Among these semiconductors, tin disulfide $\left(\mathrm{SnS}_{2}\right)$ and Copper sulfides $\left(\mathrm{Cu}_{2} \mathrm{~S}\right)$.Tin disulfide which is a layered semiconductor belongs to a $\mathrm{CdI}_{2}$-type structure with band gap of (2-3) eV $[2,3]$. Broad band gap leads to photoconductance [4], and makes it possible to be a candidate in solar cells and opto-electronic devices [5]. In general, bulk tin sulfides have been synthesized through solid state reactions metathesis and mechano chemistry [6]. Efforts solid state have also been made to grow $\mathrm{SnS}_{2}$ single crystal and thin films by chemical vapor transport (CVT) [7], physical vapor transport (PVT) [8], and spray pyrolysis [9], respectively. However, all these reported methods require either relatively high reaction temperature(more than $573 \mathrm{~K}$ ) or special reactors. Recently, many attempts have been made to seek mild and convenient preparation conditions. Whil Copper sulfides $\left(\mathrm{Cu}_{\mathrm{x}} \mathrm{S}, 1 \leq \mathrm{x} \leq 2\right)$ are interesting materials due to their special physical and chemical properties. There are several stable phases of copper sulfides at room temperature with different stoichiometry $\quad(x=2,1.95,1.8,1.75,1)$. Among them, cuprous sulfide $\left(\mathrm{Cu}_{2} \mathrm{~S}\right)$ is considered as an ideal absorber in photovoltaic conversions due to its high absorption coefficient $\left(10^{4} \mathrm{~cm}^{-1}\right)$ and narrow band gap $(1.2 \mathrm{eV})$ [10].However, degeneration of $\mathrm{Cu}_{2} \mathrm{~S}$ induced by diffusion of copper ions was found to be a fatal problemfor $\mathrm{Cu}_{2} \mathrm{~S}$ based heterojunction solar cells [11]. Recently, efforts have been made to find an alternative n-type semiconductor to

prevent ion diffusion across the interface [12]. In addition to this,

*College of science for Women ,University of Baghdad, Jadriya, Baghdad, Iraq 
amorphous $\mathrm{Cu}_{2} \mathrm{~S}$ with lower ion mobility may provide a strategy to inhibit ion diffusion in the bulk material. Thus, it is still necessary to find a simplemethod that could be applied on deposition of amorphous $\mathrm{Cu}_{2} \mathrm{~S}$ on various substrates Although many methods have been developed to prepare $\mathrm{Cu}_{2} \mathrm{~S}$ thin films, such as solid state reaction [13], CVD [6], spray pyrolysis [14], CBD [15] and SILAR $[16,17]$, few researches were conducted on amorphous $\mathrm{Cu}_{2} \mathrm{~S}$. Amorphous $\mathrm{Cu}_{2} \mathrm{~S}$ is usually formed in solution method at low temperature, however, it is unstable and crystallizes at higher temperature.

\section{2-Materail and Methods:}

$\left(\mathrm{Cu}_{2} \mathrm{~S}\right)_{100-\mathrm{x}}\left(\mathrm{SnS}_{2}\right)_{\mathrm{x}}$ films were prepared by chemical spray pyrolysis method on glass substrates at $573 \mathrm{~K}$. The effective area of the substrates was approximately $2.5 \mathrm{~cm}^{2}$. The deposition parameters such as solution flow rate; and nozzle to substrate distance were kept constant at $5 \mathrm{ml} / \mathrm{min}$, and $(30 \pm 1)$ $\mathrm{cm}$, respectively.Copper sulphide solution was prepared using $\mathrm{CuCl}_{2} \cdot 2 \mathrm{H}_{2} \mathrm{O}$ and thiourea. Firstly, thiourea was dissolved in a minimum amount of deionized water while Copper Chloride $\left(\mathrm{CuCl}_{2} \cdot 2 \mathrm{H}_{2} \mathrm{O}\right)$ was dissolved in a water. Secondly, both solutions were mixed and diluted with deionized water, so that the final concentration was $0.1 \mathrm{M}$. While tin sulphide solution was prepared using $\mathrm{SnCl}_{4} .5 \mathrm{H}_{2} \mathrm{O}$ and thiourea. Firstly, thiourea was dissolved in a minimum amount of deionized water while Tin Chloride $\left(\mathrm{SnCl}_{4} .5 \mathrm{H}_{2} \mathrm{O}\right)$ was dissolved in a Water. Secondly, both solutions were mixed and diluted with deionized water, so that the final concentration was 0.1 M.After both solutions of Copper sulphide and tin sulphide were mixed at ratio $30 \%, 40 \%$ and $50 \%$. Table (1) illustrates the variation of the ratio values of the $\left(\mathrm{Cu}_{2} \mathrm{~S}\right)_{100-\mathrm{x}}\left(\mathrm{SnS}_{2}\right.$ )$_{\mathrm{x}}$ which were then sprayed onto the heated substrates. The substrates were ultrasonically cleaned, first with trichloroethylene and then with acetone and methyl alcohol followed by rinsing in distilled water. The solution was stored in a volumetric reservoir at room temperature and connected to one side of the spray nozzle. The carrier gas, air was allowed to flow ( 8 $1 /$ min.) through the pressuremonitoring gauge, connected to the other side of the spray nozzle. The spray nozzle was moved in the $x-y$ plane using themicroprocessor controlled stepper motor system in order to a achieve uniform film coating. Moving the spray nozzle is just an option, so, it is possible to work in a stationary position too with the same setup.

Table (1) the variation of the ratio values of the $\left(\mathrm{Cu}_{2} \mathrm{~S}-\mathrm{SnS}_{2}\right)$.

\begin{tabular}{|l|l|l|}
\hline Percentage & $\mathbf{C u}_{2} \mathbf{S}$ & $\mathbf{S n S}_{\mathbf{2}}$ \\
\hline $30 \%$ & 70 & 30 \\
\hline $40 \%$ & 60 & 40 \\
\hline $50 \%$ & 50 & 50 \\
\hline
\end{tabular}

\section{3- Optical properties}

The optical properties of the films deposited on glass substrates are determined from the absorbance (A) and transmittance $(\mathrm{T})$ measurements in the range (310-1100) $\mathrm{nm}$. that the transmittance increasing with increasing wavelength of $\left(\mathrm{Cu}_{2} \mathrm{~S}\right)_{100-\mathrm{x}}($ $\left.\mathrm{SnS}_{2} \quad\right)_{\mathrm{x}}$ those found that the transmittance increases with increasing wavelength of $\mathrm{Cu}_{2} \mathrm{~S}$ for all ratio this results agree with Fuwei Zhuge et al. [10], Ashour et al. [18]. Also Kaliannan , Thangaraju[19], Khelia et al. [20],A.Sanchez et al. [21]. those found the transmittance of $\mathrm{SnS}_{2}$ increase with increasing wave length. Whil the compound thin films 
the transmittance decreases with increasing the ratio of $\mathrm{SnS}_{2}$. Figure (1) illustrates the transmittance spectra of $\left(\mathrm{Cu}_{2} \mathrm{~S}\right)_{100-\mathrm{x}}\left(\mathrm{SnS}_{2}\right)_{\mathrm{x}}$ thin films at $(\mathrm{RT}$ , 373,423 \& 473) $\mathrm{K}$ for $\mathrm{X}=[50,40$, $\& 30)] \%$. It is clear from this figure that the transmittance of $\left(\mathrm{Cu}_{2} \mathrm{~S}\right)_{100-\mathrm{x}}\left(\mathrm{SnS}_{2}\right)_{\mathrm{x}}$ thin films increases with the increase in the annealing temperature for all values of ratio. This indicates that annealing imparts the film's atoms the sufficient energy to diffuse more easily through the crystal structure of the film and leads to and nedal [23] who found that the transmittance increases with the increasing in the annealing temperatures. Fig. (2). It is clear the absorbance of the mixture thin films the absorbance increase with increasing the ratio of $\mathrm{SnS}_{2}$. The absorbance spectra of $\left(\mathrm{Cu}_{2} \mathrm{~S}-\mathrm{SnS}_{2}\right)$ thin films at (RT , 373,423 \& 473) K for $X=[50,40, \& 30)] \%$ are illustrated in figure (2). It can be observed from this figure that the absorbance of $\left(\mathrm{Cu}_{2} \mathrm{~S}\right)_{100-\mathrm{x}}\left(\mathrm{SnS}_{2}\right)_{\mathrm{x}}$ thin films decreases with the increasing in annealing temperature for all ratio of the mixture . This is attributed that increasing in the transmittance of $\left(\mathrm{Cu}_{2} \mathrm{~S}-\mathrm{SnS}_{2}\right)$ thin films with the increase in annealing temperature since the absorbance is related to the transmittance according to eq.

$$
\mathrm{A}=\log _{10}\left(\frac{1}{\mathrm{~T}}\right)
$$

Our results agree with nedal [23], who found that the absorbance decreases with the increasing in annealing temperature for $\mathrm{SnS}_{2}$
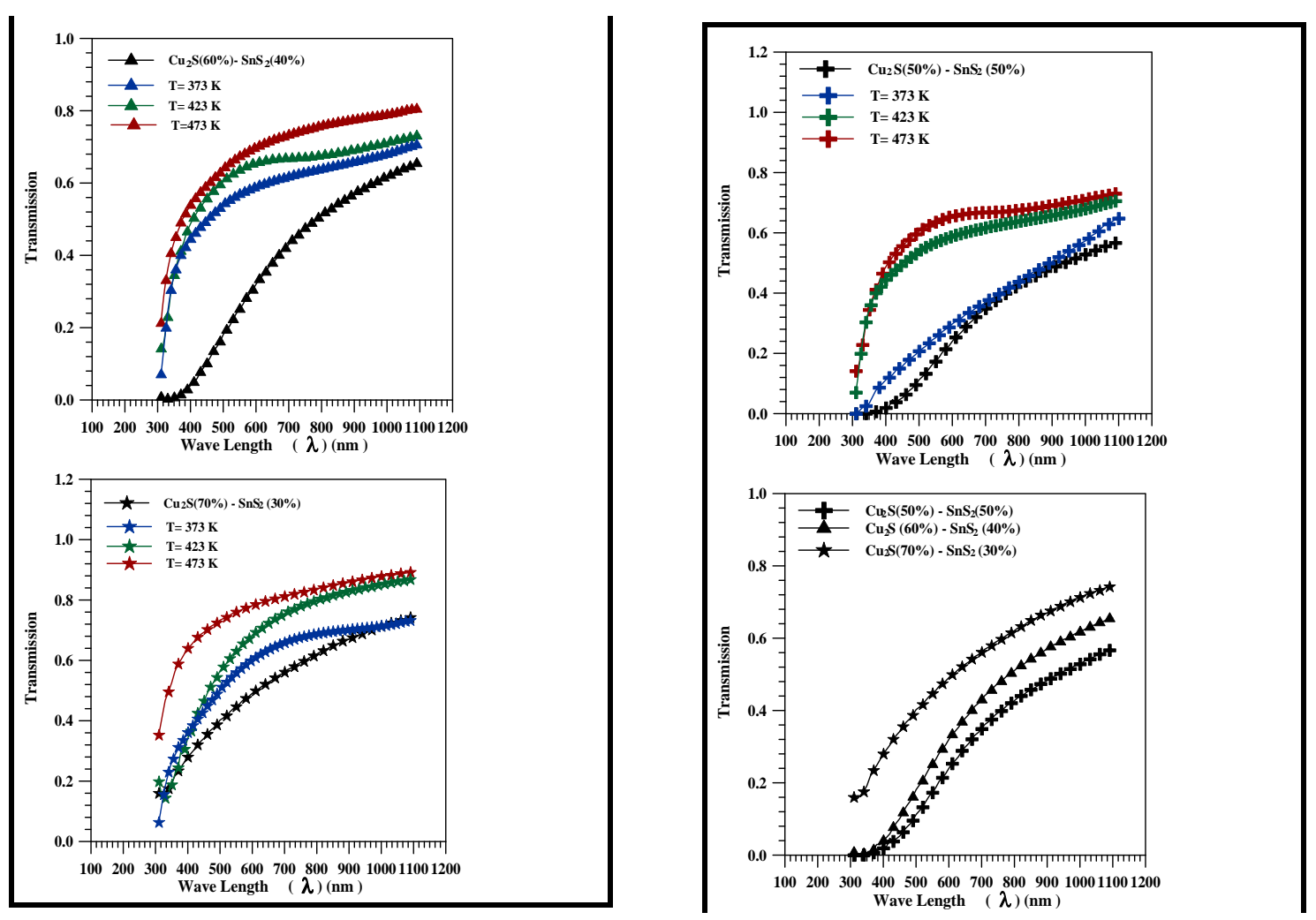

Fig.(1):Transmittance spectrums of $\left(\mathrm{Cu}_{2} \mathrm{~S}\right)_{100-\mathrm{x}}\left(\mathrm{SnS}_{2}\right)_{\mathrm{x}}$ thin films at different annealing temperature and different ratio 

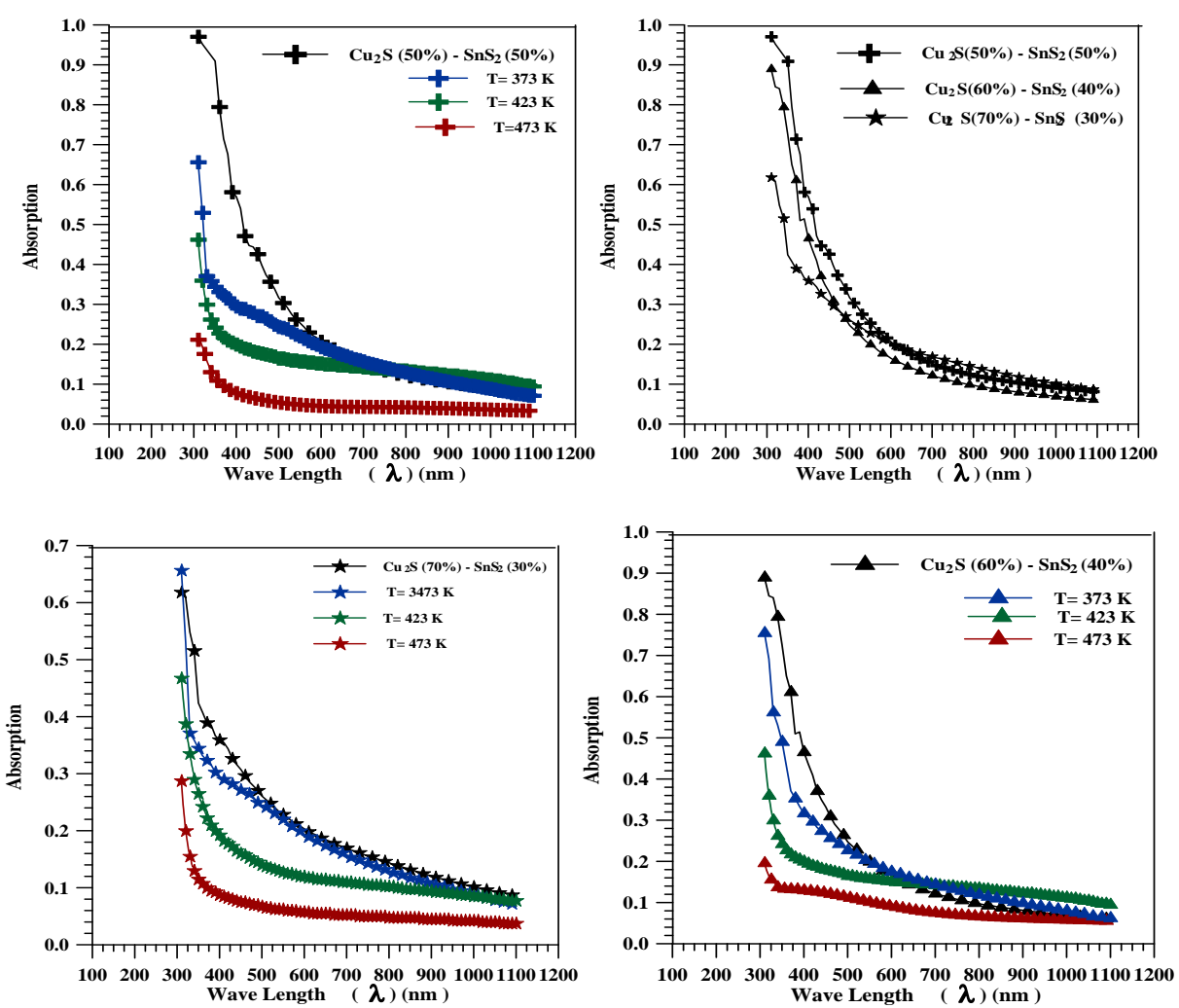

Fig.(2):Absorbance spectrums of $\left(\mathrm{Cu}_{2} \mathrm{~S}\right)_{100-\mathrm{x}}\left(\mathrm{SnS}_{2}\right)_{\mathrm{x}}$ thin films at different annealing temperature and different ratio

figure (3) is clear that the optical energy gap for $\left(\mathrm{Cu}_{2} \mathrm{~S}-\mathrm{SnS}_{2}\right)$ thin films decreases as the $\mathrm{SnS}_{2}$ ratio in the films increases from $(2.22-2.26) \mathrm{eV}$. This is attributed to the decrease of $\mathrm{S}$ concentration (Sulfur vacancies increase) which leads to an increasing of the depth of donor levels associated with these vacancies which in turn cause a reduction in the optical energy gap for $\left(\mathrm{Cu}_{2} \mathrm{~S}\right)_{100-\mathrm{x}}\left(\mathrm{SnS}_{2}\right)_{\mathrm{x}}$ thin films .
The variation of the optical energy gap $\left(\mathrm{E}_{\mathrm{g}}\right)$ of $\left(\mathrm{Cu}_{2} \mathrm{~S}\right)_{100-\mathrm{x}}\left(\mathrm{SnS}_{2}\right)_{\mathrm{x}}$ thin films with annealing temperature is listed in table (2) . It is obvious from this table that $\mathrm{E}_{\mathrm{g}}$ at $\left.\mathrm{X}=[50,40, \& 30)\right] \%$ increases with the increase in annealing temperature for all ratio of the mixture . Our results agree with J. SANTOS CRUZ et al. [24], nedal [23] 


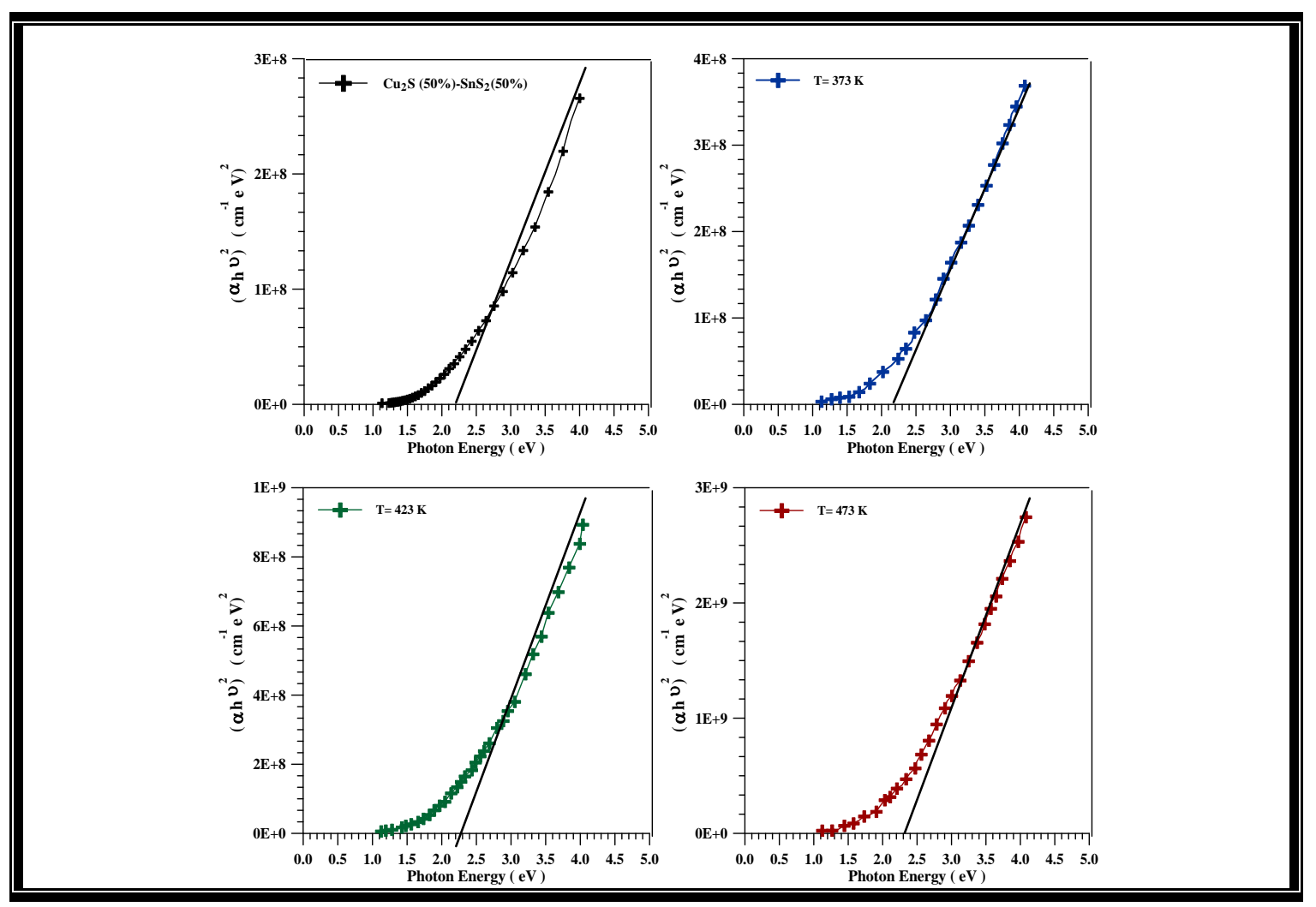

Fig.(3a) : $(\alpha h v)^{2}$ as a function of ho for $\left(\mathrm{Cu}_{2} \mathrm{~S}\right)_{100-\mathrm{x}}\left(\mathrm{SnS}_{2}\right)_{\mathrm{x}}$ thin films

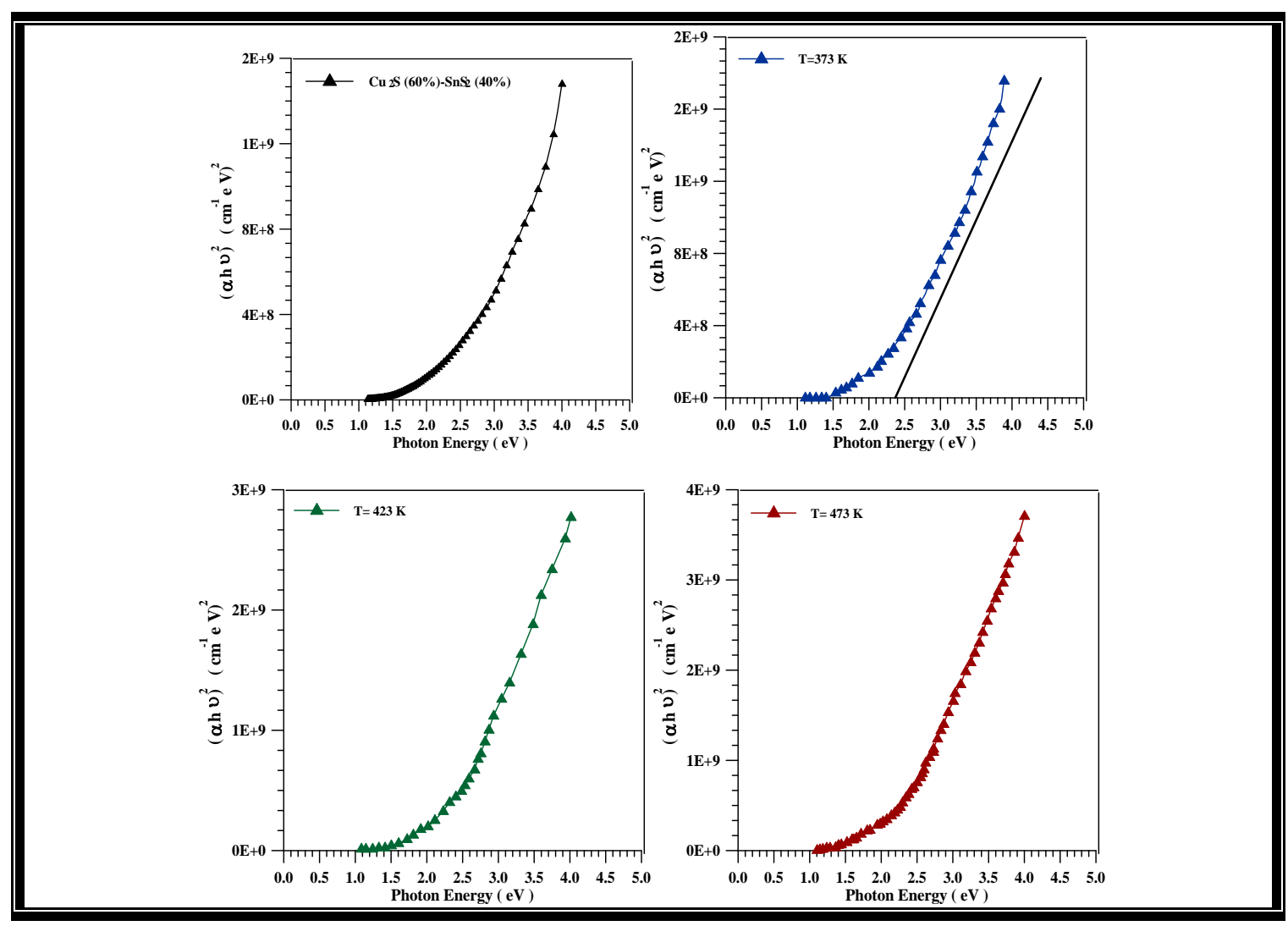

Fig.(b3) : $(\alpha h v)^{2}$ as a function of hv for $\left(\mathrm{Cu}_{2} \mathrm{~S}\right)_{100-\mathrm{x}}\left(\mathrm{SnS}_{2}\right)_{\mathrm{x}}$ thin films 

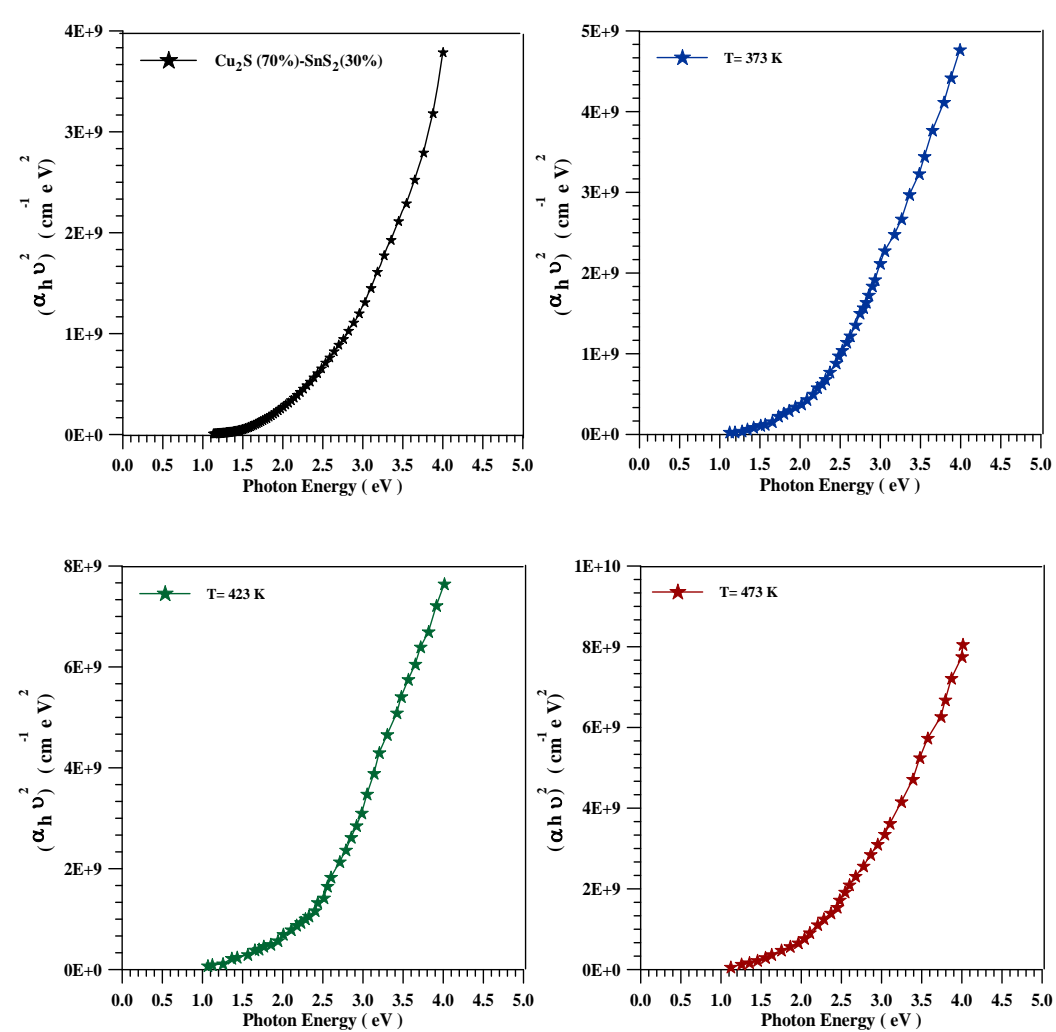

Fig.(c3) : $(\alpha h v)^{2}$ as a function of ho for $\left(\mathrm{Cu}_{2} \mathrm{~S}\right)_{100-\mathrm{x}}\left(\mathrm{SnS}_{2}\right)_{\mathrm{x}}$ thin films

Table (2)

\begin{tabular}{|c|c|c|c|c|}
\hline \multirow{2}{*}{ Film } & \multicolumn{4}{|c|}{ Eg (eV) } \\
\cline { 2 - 5 } & $\begin{array}{c}\text { RT } \\
(\mathbf{K})\end{array}$ & $\begin{array}{c}\mathbf{3 7 3} \\
(\mathbf{K})\end{array}$ & $\begin{array}{c}\mathbf{4 2 3} \\
(\mathrm{K})\end{array}$ & $\begin{array}{c}\mathbf{4 7 3} \\
(\mathrm{K})\end{array}$ \\
\hline $\begin{array}{c}\mathbf{C u}_{2} \mathbf{S}(\mathbf{5 0 \%})- \\
\mathbf{S n S}_{\mathbf{2}}(\mathbf{5 0 \%})\end{array}$ & 2.22 & 2.25 & 2.3 & 2.32 \\
\hline $\begin{array}{c}\mathbf{C u}_{\mathbf{2}} \mathbf{S}(\mathbf{6 0 \%})- \\
\left.\mathbf{S n S}_{\mathbf{2}} \mathbf{4 0 \%}\right)\end{array}$ & 2.24 & 2.27 & 2.29 & 2.33 \\
\hline $\begin{array}{c}\mathbf{C u}_{2} \mathbf{S}(\mathbf{7 0 \%})- \\
\mathbf{S n S}_{\mathbf{2}}(\mathbf{3 0 \%})\end{array}$ & 2.26 & 2.28 & 2.32 & 2.38 \\
\hline
\end{tabular}

The variation of refractive index (n) of thin films have been determined by using the following equation

$n=\sqrt{\frac{4 R}{(R-1)^{\wedge} 2}}-\mathrm{K}^{\wedge} 2-\left(\frac{R+1}{R-1}\right)$

Where , $R$ is the reflectance of the films and $\mathrm{k}$ is the extinction coefficient

figure (4) is clear the refractive index of $\left(\mathrm{Cu}_{2} \mathrm{~S}\right)_{100-x}\left(\mathrm{SnS}_{2}\right)_{x}$ thin films for all ratio decreases with the increase in ratio of $\mathrm{SnS}_{2}$ Figure (4) illustrates the variation of the refractive index with the photon energy for $\left(\mathrm{Cu}_{2} \mathrm{~S}\right.$ $\mathrm{SnS}_{2}$ )thin films at (RT , 373,423 \& 473) $\mathrm{K}$ for $\mathrm{X}=[50,40, \& 30)] \%$. It can be observed from this figure that the refractive index of $\left(\mathrm{Cu}_{2} \mathrm{~S}\right)_{100-x}\left(\mathrm{SnS}_{2}\right)_{x}$ thin films increases with the increasing in annealing temperature for all ratio of the mixture The extinction coefficient (k) have been determined by using the following equation

$$
\mathrm{k}=\frac{\alpha \lambda}{4 \pi}
$$

Where,$\alpha$ is the absorption coefficient and $\lambda$ is the wave length of the incident photon.

It is clear from this equation that $\mathrm{k}$ depend on $\alpha$ and has asimilar behavior to $\alpha$.

figure is clear that The extinction coefficient increase with the increasing in the ratio of $\mathrm{SnS}_{2}$. This is because the increase in the absorption coefficient 
due to the increasing in the depth of donor levels associated with sulfur vacancies. These levels will be available for the photons to be absorbed causing an increment in the absorbance and leading to an increase in the absorption coefficient. From thi figure( 5 )it can be noted that the extinction coefficient of $\left(\mathrm{Cu}_{2} \mathrm{~S}\right)_{100-}$ ${ }_{x}\left(\mathrm{SnS}_{2}\right)_{\mathrm{x}}$ thin films decreases with the increasing in annealing temperature for all values of ratio . Because annealing leads to the overcoming of some of local states and then decreases the absorbance and increases the transmittance.

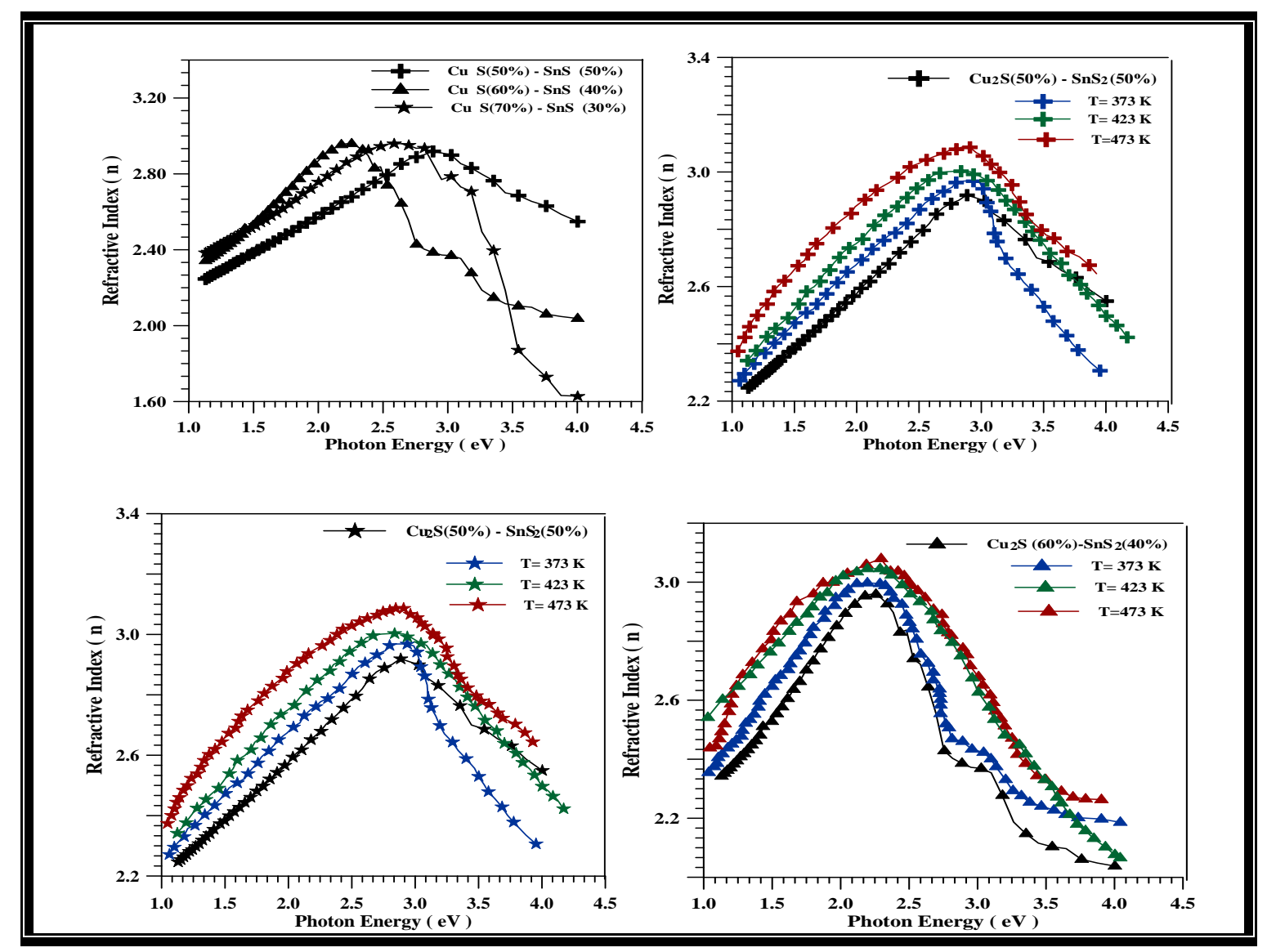

Fig.(4):Refractive index of $\left(\mathrm{Cu}_{2} \mathrm{~S}\right)_{100-\mathrm{x}}\left(\mathrm{SnS}_{2}\right)_{\mathrm{x}}$ thin films at different annealing temperature and different ratio 


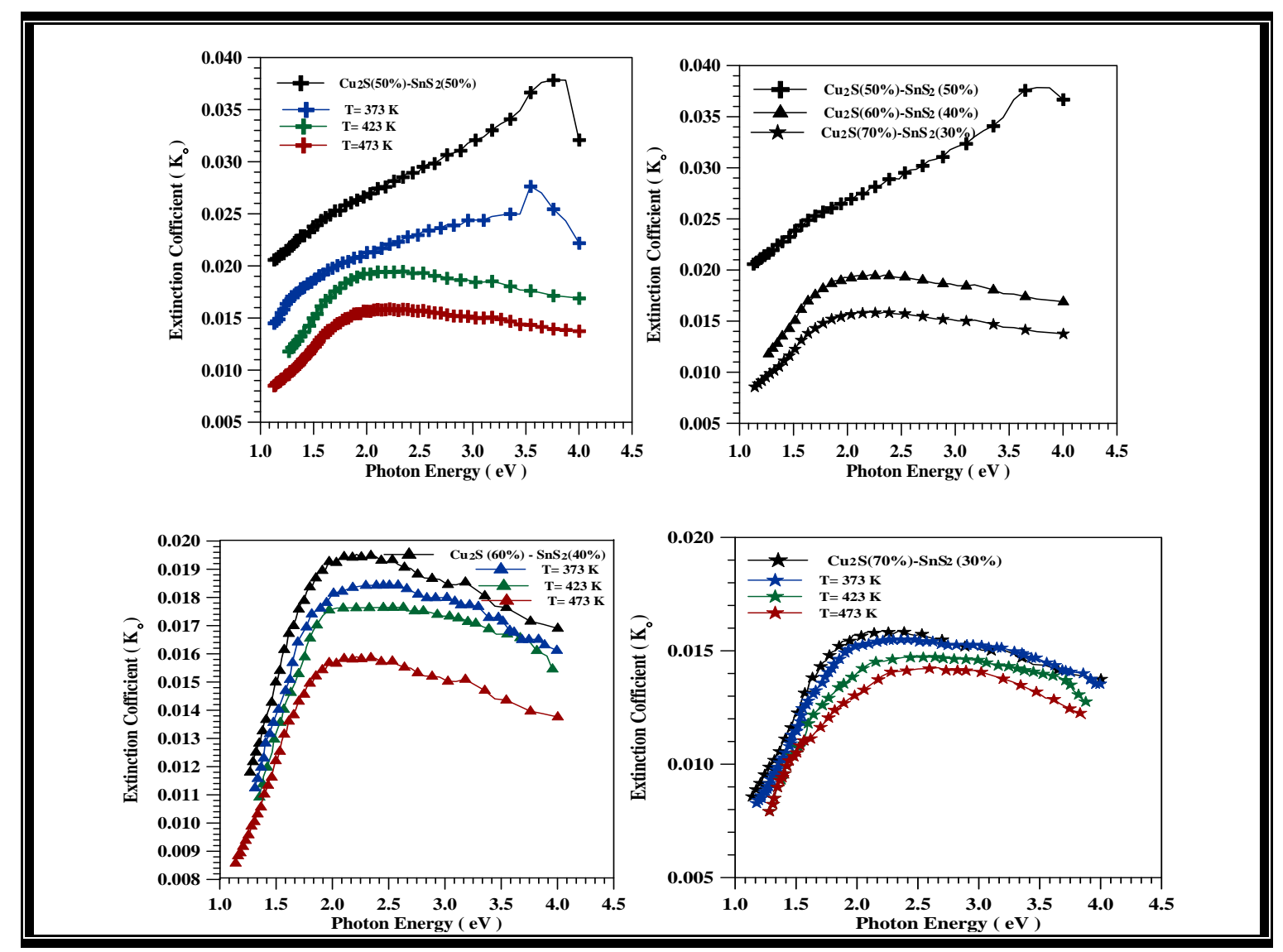

Fig.(5): Extinction coefficient of $\left(\mathrm{Cu}_{2} \mathrm{~S}\right)_{100-\mathrm{x}}\left(\mathrm{SnS}_{2}\right)_{\mathrm{x}}$ thin films at different annealing temperature and different ratio

It is also clear that the real part of the dielectric constant of $\left(\mathrm{Cu}_{2} \mathrm{~S}\right)_{100-\mathrm{x}}($ $\left.\mathrm{SnS}_{2}\right)_{\mathrm{x}}$

thin films increases with the decrease in $\mathrm{SnS}_{2}$ ratio due to the dependence of the real part of the dielectric constant on the refractive index values, where the refractive index increases with the decrease in $\mathrm{SnS}_{2}$ ratio. figure(6)It is clear that the real parts of the dielectric constant of $\left(\mathrm{Cu}_{2} \mathrm{~S}\right)_{100-\mathrm{x}}\left(\mathrm{SnS}_{2}\right)_{\mathrm{x}}$ thin films increase with the increase in annealing temperature. This is attributed to the dependence of the real and imaginary parts of the dielectric constant on the refractive index and the extinction coefficient respectively, as mentioned and discussed previously in the item. figure (7) . It is clear that the increase in the $\mathrm{SnS}_{2}$ ratio leads to an increase in the imaginary part of the dielectric constant of $\left(\mathrm{Cu}_{2} \mathrm{~S}\right)_{100}$ ${ }_{x}\left(\mathrm{SnS}_{2}\right)_{\mathrm{x}}$ thin films. This is attributed to the dependence of the imaginary part of the dielectric constant on the extinction coefficient values, where the extinction coefficient increases with the increase in the $\mathrm{SnS}_{2}$ ratio. It can be observed from this figure that the imaginary parts of the dielectric constant of $\left(\mathrm{Cu}_{2} \mathrm{~S}\right)_{100-\mathrm{x}}\left(\mathrm{SnS}_{2}\right)_{\mathrm{x}}$ thin films decrease with the increase in annealing temperature . This is attributed to the dependence of the imaginary parts of the dielectric constant on the refractive index and the extinction coefficient respectively, as mentioned and discussed previously in the 

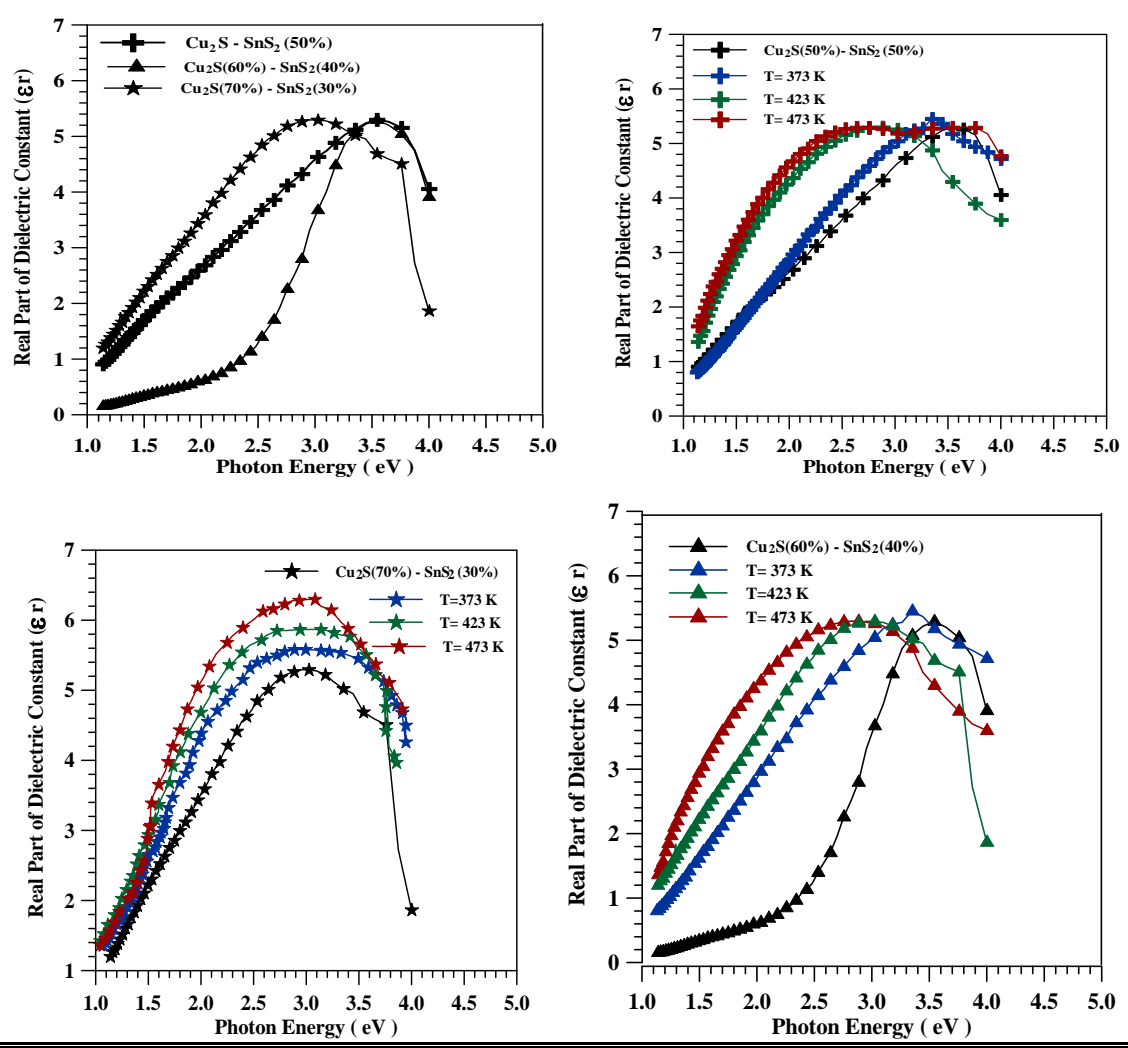

Fig.(6):The real part of the dielectric constant of $\left(\mathrm{Cu}_{2} \mathrm{~S}\right)_{100-\mathrm{x}}\left(\mathrm{SnS}_{2}\right)_{\mathrm{x}}$ thin films at different annealing temperature and different ratio

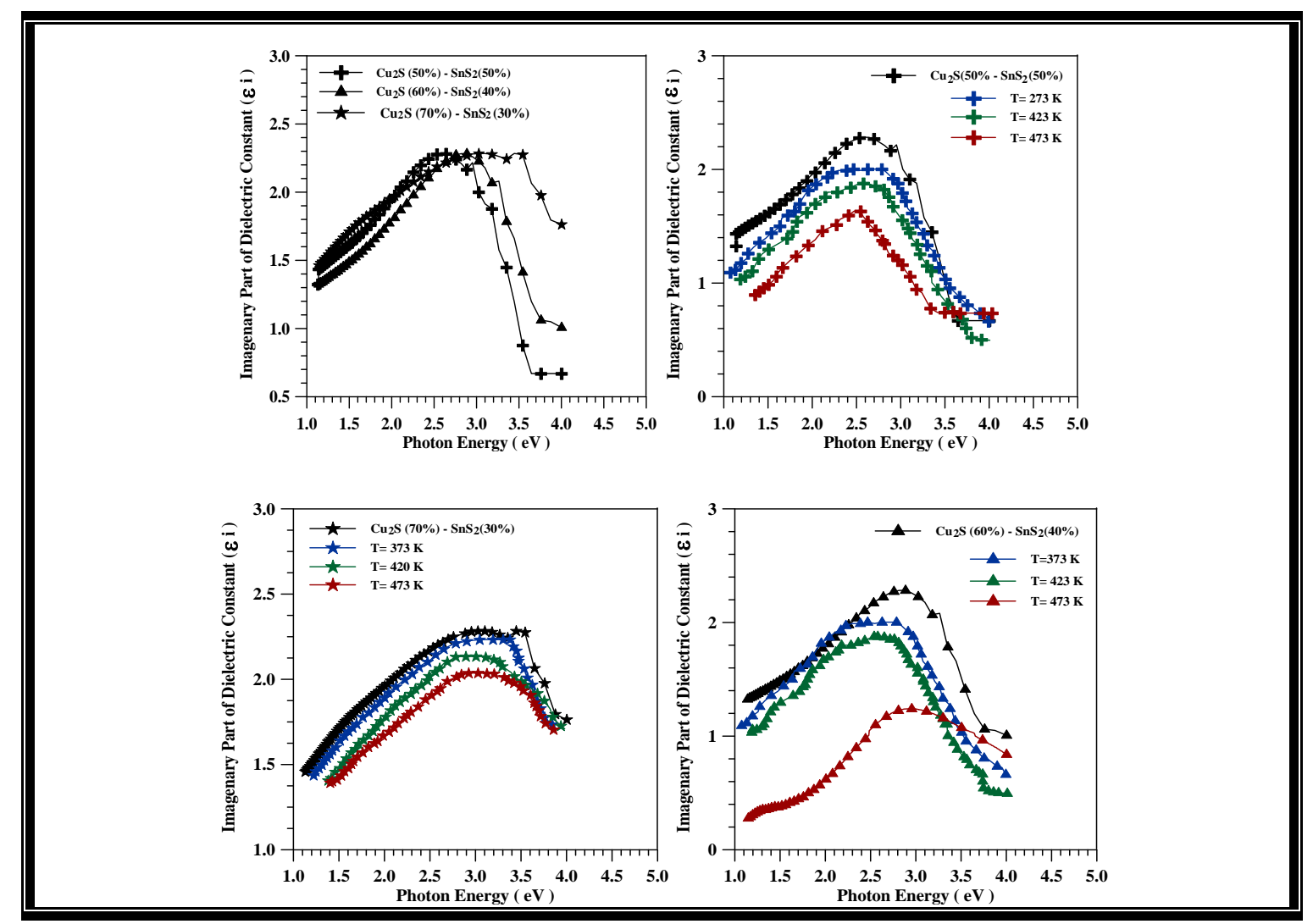

Fig.(7):The imaginary part of the dielectric constant of $\left(\mathrm{Cu}_{2} \mathrm{~S}\right)_{100-\mathrm{x}}\left(\mathrm{SnS}_{2}\right)_{\mathrm{x}}$ thin films at different annealing temperature and different ratio 


\section{Conclusion:}

Chemical spray pyrolysis method technique can be successfully employed for the deposition of uniform optical properties of $\left(\mathrm{Cu}_{2} \mathrm{~S}\right)_{100-\mathrm{x}}\left(\mathrm{SnS}_{2}\right)_{\mathrm{x}}$ thin films. Optical studied indicates that $\left(\mathrm{Cu}_{2} \mathrm{~S}\right)_{100-\mathrm{x}}\left(\mathrm{SnS}_{2}\right)_{\mathrm{x}}$ thin films exhibit direct band gap which is strongly depends on the $\mathrm{SnS}_{2}$ ratio .The band gap decreases with the increasing $\mathrm{SnS}_{2}$ ratio, while it increasing with the increase in the annealing temperature at all ratio almost cover the entire visible spectral that makes these films are suitable for optoelectronic devices especially for solar cell .

\section{References:}

1-Bin Hai, Kaibin Tang*, Chunrui Wang, Changhua An, Qing Yang, Guozhen Shen, Yitai Qian . 2001."Synthesis of $\mathrm{SnS}_{2}$ nanocrystals via a solvothermal process", "Journal of Crystal Growth ", 225 (2001): 9295.

2-J Gajendiran and V Rajendran 2011. "Synthesis of $\mathrm{SnS}_{2}$ nanoparticles by a surfactant-mediated hydrothermal method and their characterization", "Nat. Sci.: Nanosci. Nanotechnol", 2 (1) :15-20.

3- G. Domingo, R.S. Itoga, C.R. Cannewurf.1966.

"Fundamental

Optical Absorption in $\mathrm{SnS}_{2}$ and $\mathrm{SnSe}_{2}$ ", "Phys. Rev", 143( 536):160165.

4- S. Polarz, B. Smarsly, C. Goltner, M. Antonietti . 2000 ." The Interplay of Colloidal Organization and OxoCluster Chemistry: PolyoxometalateSilica Hybrids-Materials with a Nanochemical Function "," Adv. Matter", $12: 1503$.

5- J. Morales, V.C. Perez, J. Santos, L.J. Tirado .1996 ." Electrochemical characteristics of crystalline and amorphous SnS2 in lithium cells", "J. Electrochem. Soc". 143 (9)22-27.
6- P. Balaz, T. Ohtani, Z. Bastl, E. Boldizarova . 1999. "Properties and Reactivity of Mechanochemically Synthesized Tin Sulfides", "Journal of Solid State Chemistry",

144: 1-7.

7- T.Shibata, T. Miura, T. Kishi, T. Nagai .1990 ." Chemical and structural characterization of $\mathrm{SnS}_{2}$ single crystals grown by low-temperature chemical vapour transport "J. Crystal Growth ",106 (593)34-39.

8-J. George, C.K. Valsala Kumari" . 1983 . " Growth and characterization of tin disulphide crystals grown by physical vapour transport method"," J. Crystal Growth",63(233) 80-87.

9- A. Ortiz, S. Lopez . 1994. "Spray pyrolysis deposition of $\mathrm{Sn}_{\mathrm{x}} \mathrm{S}_{\mathrm{y}}$ thin films ",,"Semicond. Sci. Technol",9 2130.

10-Fuwei Zhuge, Xiaomin $\mathrm{Li}$, Xiangdong Gao, Xiaoyan Gan, Fengling Zhou . 2009. "Synthesis of stable amorphous $\mathrm{Cu}_{2} \mathrm{~S}$ thin film by successive ion layer adsorption and reaction method"," Materials Letters", 63: 652-654

11- Liu GM, Schulmeyer T, Brotz J, Klein A, Jaegermann W. 2003 ." Electronic transport and semiconductors ", " Appl Phys Lett ", 431:477-82.

12- Parkin IP. 1996. "Solid state metathesis reaction for metal borides, silicides, pnictides and chalcogenides: ionic or elemental pathways", " Chem Soc Rev ", 25(3):199-207.

13- Schneider S, Ireland JR, Hersam MC, Marks TJ . 2007. "Copper(I) tertbutylthiolato clusters as single-source precursors for high-quality chalcocite thin films: Film growth and microstructure control," " Chem Mater ", 19(11)54-59.

14-1.a. Isac L, Duta A, Kriza A, Manolache S, Nanu M . 2007 ." crystal order in $\mathrm{Cu}_{2} \mathrm{~S}$ thin film s obtained by spray pyroysis "," journal of optoelectronics and advanced materials ", 9 (5): 1265-1268. 
15- Bagul SV, Chavhan SD, Sharma R. of $\mathrm{Cu}_{\mathrm{x}} \mathrm{S}(\mathrm{x}=1.0,1.76$, and 2.0) thin films grown by solution growth technique (SGT)", "Phys Chem Solids", 68(9):1623.

16- Pathan HM, Desai JD, Lokhande CD. 2002. "Modified chemical deposition and physico-chemical properties of copper sulphide $\left(\mathrm{Cu}_{2} \mathrm{~S}\right)$ thin films", " Appl Surf Sci",

56( 202): 47-56.

17- Lindroos S, Arnold A, Leskela M. 2000." Growth of CuS thin films by the successive ionic layer adsorption and reaction method","Appl Surf Sci ",158(1-2):75-80.

18- . A.Ashour . 2006 .,"The physical characteristics of $\mathrm{Cu}_{2} \mathrm{~S} / \mathrm{CdS}$ thin film solar cell Journal of Optoelectronics and advannnnced materials ", "Journal of Optoelectronics and advannnnced materials ", 8( 4 ):1447-1451.

19- B. Thangaraju and P. Kaliannan . 2000." Spray pyrolytic deposition and characterization of $\mathrm{SnS}$ and $\mathrm{SnS}_{2}$ thin films", "J . Phys. D: Appl ". 33 :10541059.

20- C.Khelia,K.Boubaker and M.Amlouk 2009."Boubaker polynomials expansion scheme related optical properties of $\beta$ - $\mathrm{SnS}_{2}$
J. 2007." Growth and characterization sprayed layers", "Fizika A", 18 (2):81-88.

21- A.Sanchez-Juar ez,A.TiburcioSilver,A.Ortiz . 2005. "Fabrication of $\mathrm{SnS} 2 / \mathrm{SnS}$ heterojunction thin film diodes by plasma-enhanced chemical vapor deposition", "Thin Solid Films", 480(481):452-456.

22-Zhongbin Zhuang, Qing Peng, Boce Zhang, and Yadong Li ,2008." Controllable Synthesis of $\mathrm{Cu}_{2} \mathrm{~S}$ Nanocrystals and Their Assembly into a SuperlatticeSOC", "B J. AM. CHEM". 9

23-Nedal ali Mahmood . 2007." A Study of the Structural and Optical Properties of

$\left(\mathrm{SnS}_{2}: \mathrm{Cu}\right)$ Prepared by Chemical Spray Pyrolysis, M.Sc. Thesis, University of Baghdad.

24- J. Santos cruz, S. A. mayen hernanddez, J. J. coronel hernandez , R. mejiarodriguez, R. castanedo pereza, G. torres delgadoa, S. jamenez sandovala . 2012." Characterization of $\mathrm{Cu}_{\mathrm{x}} \mathrm{S}$ thin films obtained by CBD technique at differents annealing temperatures", Chalcogenide Letters", 9(2): 85 - 91.

$$
\begin{aligned}
& \text { تأثثير التثلين على الخصائص البصرية لأغثية } \\
& \text { نادية جاسم غضبب } \\
& \text { انوار علي باقرث } \\
& \text { نلدى خضبر عباس" } \\
& \text { *قسم الفيزياء / كلية العلوم للبنات }
\end{aligned}
$$

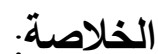

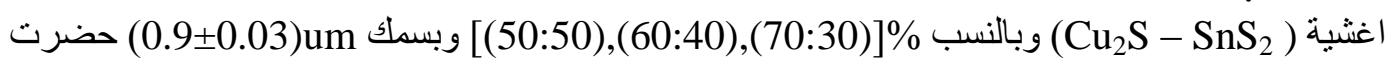

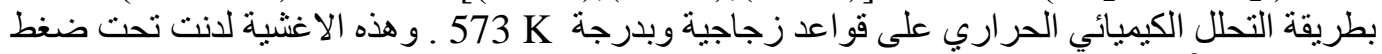

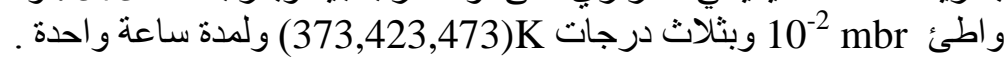

$$
\begin{aligned}
& \text { هذا البحث يتضمن در اسة الخصائص البصرية ل }
\end{aligned}
$$

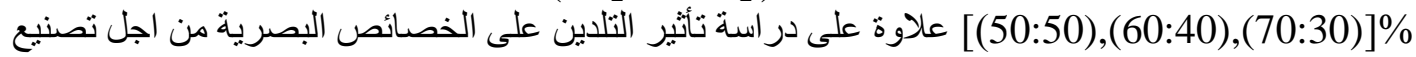

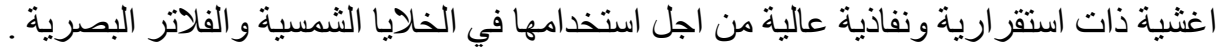

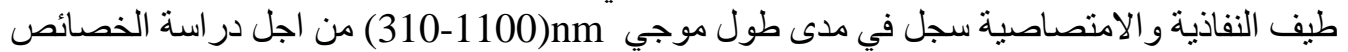

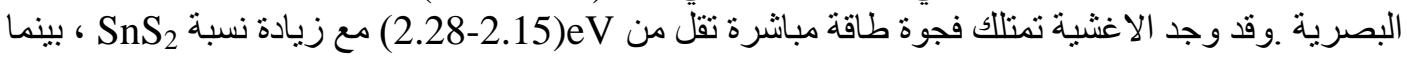

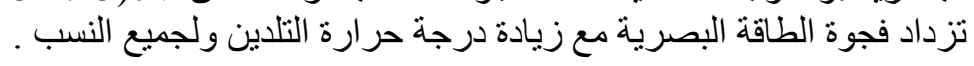

